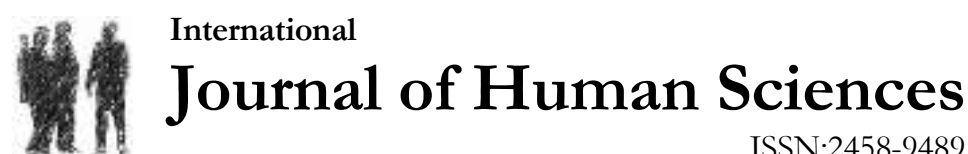

Volume 14 Issue 4 Year: 2017

\section{The evaluation of short-term nutrition education on the nutrition habits of university students}

\author{
Çiğdem Sabbağ $\breve{g}^{1}$
}

\begin{abstract}
Nutrition education provision during adolescence and its continuation in university have high impact for sustaining physically, mentally and socially healthy societies. Moreover, when a positive manner in nutrition habits is achieved following this activity, it is considered as a successful prosperity that continues lifelong. Because each age groups nutrition differs than other. The study was undertaken with the participation 395 students out of which 250 were female and 145 were. Questionnaires were undertaken for assessing any change in students' nutritional habits following 20 hours of nutrition education. Results revealed $83.3 \%$ change in students' nutrition habits following education program. Female students had internalized healthy food choice than male students by consuming more fruit and decreasing fast food preferences along with taking more care on controlling food label and expire dates of foods. These behaviors found statistically important with $\mathrm{p}<0.05$ and effect of even a short period education was manifested. The next step would be to provide information that will increase the continuity and traceability of the nutrition training to course content planners in educational institutions. Because permanent habit development should be the main target for achieving successful results following nutritional education.
\end{abstract}

Keywords: Nutrition education; Behavior; Consumption; Nutrition Habits.

\section{Introduction}

Informing on nutrition is a key component for healthy and quality life for the development and maintenance of health in each period from childhood to youth, from adulthood to senescence. Physical activity and nutrition play an important role in preventing cardiovascular diseases, cancer, diabetes and obesity (Gaglianone et al., 2006). Although chronic diseases seen during adulthood, the main reasons are due to inadequate, unhealthy and unconscious eating habits during childhood and youth (Garipoğlu et al., 2006). The negative changes in behavior alike poor eating and decrescent physical activity habits lead to adverse health consequences (Gubbels et al., 2013); this give rise to an increase in health expenditures and a decrease in productivity (Hayaloğlu and Bal, 2015).

The obesity care expenses in develop countries varied from 2 to $7 \%$ of the total health expenditures. We thought that Turkey's obesity care budget may be around 0.510 to 1.7 billion USD out of its 25.5 billion annual health expenses in 2014 (TSI, 2015). For example, in a study investigating the prevalence of obesity in Mexico, a $1 \%$ reduction in BMI would have saved $\$ 43$ million in 2030 and \$ 85 million in 2050 for health expenditures (Rtveladze et al., 2014). World

\footnotetext{
1 Assoc. Prof. Dr., University of Adiyaman, Faculty of Tourism, Department Food and Beverage Management, csabbag06@gmail.com
} 
Sabbağ, Ç. (2017). The evaluation of short-term nutrition education on the nutrition habits of university students. Journal of Human Sciences, 14(4), 3634-3644. doi:10.14687/jhs.v14i4.4702

Health Organization (WHO) suggested providing more importance to preventive medicine services by well-balanced nutrition than hospital care in order to reduce health expenses and transfer these high budgets to economic growth (WHO, 2010).

Nutrition information will increase the development of countries by ensuring efficiency and success in school and work life, such as reducing health spending. Grosso et al. (2013), noted that information is also effective in food selection except psychological and environmental factors. It has been observed that nutritional education given to middle school students has significant changes in nutritional information and dietary changes (Lee et al., 2014). In the study conducted in England, it has been concluded that nutrition knowledge which is the determinant of eating behavior, relationship between healthy eating habits in university students and use of label information and education programs should be established (Cooke and Papadaki, 2014).

In general, it is thought that education is effective on dietary habits and healthy living (Rustad and Smith 2013; Grosso et al., 2013; Lee et al., 2014) although at occasions education programs may not be positively effective on eating behaviors (Bravo et al., 2006). A positive relationship between nutrition knowledge and eating habits were determined by Grosso et al., (2013) and Spronk et al., (2014). Between genders, the level of nutrition knowledge was higher in women compared to men (Wardle et al., 2000). It is also stated that identification of nutritional habits and nutrition knowledge rising generation is essential for assessing current and future health status of a society (Epuru and Shammary, 2014). Nutrition education guides every segment of society to make intelligent decisions on physiological health and the food and lifestyle that support their economic situation, as well as aim to acquire healthy eating behaviors (Gil, 2010; USDA, 2012) that focus health food and nutrition literacy.

In this context, it is required to start nutritional education for all age groups from childhood in order to reduce the eating related health disorders (Lange, 2017). Mandatory adverse changes in eating habits are often seen in university students living away from the family or making more independent decisions (Levitsky et al., 2004) that can lead to negative health behaviors such as smoking and alcohol drinking. Moreover, unhealthy diets for gaining a better looking physical structure along with not participating in sports events due to living in a different social environment with adaptation problems all resulted unhealthy outcomes. Illhan et al., (2010) observed that economic status and education continuum of university students have a positive effect on their preferred lifestyle behaviors. It is known that the consumption of low-nutrient foods with high energy value such as fast food is increased instead of traditional foods with the rise in the economic level (Çekal, 2008). It has been reported that university students have i) significantly inadequate daily fruit and vegetable consumption, which should be neatly consumed for healthy living (El Ansari et al., 2011), ii) have common fast food-style consumption (Dingman et al., 2014), and iii) have a limited physical activity (Irwin 2004), and consequently the obesity rate was high due to unbalanced feeding (Peltzer et al., 2014). Grosso et al. (2013) and Spronk et al. (2014) determined a positive relationship between nutrition knowledge and eating habits. The nutrition knowledge was generally higher in women compared to men by Wardle et al. (2000).

Nutrition knowledge although an important in food selection, it may not develop behavior and can often be a decisive factor in nutritional decisions (Haslam et al., 2000). Inadequate knowledge, attitude and false beliefs are the main obstacles to behavior change (Khajvy et al., 2001).

Generally, fast food consumption increased the risk of obesity especially when their physical activity is low among youngsters. The nutritional education given to students may be able to reduce obesity, which is a global problem and unhealthy lifestyle. It should be considered that the knowledge of the future parents will contribute to the formation of healthy society by sturdy growth of the next generation. Thus, nutrition literacy is an holistic approach that contains creating information awareness on food and nutrition for guiding good choices for sustaining smart and healthy eating as consuming adequate amounts of healthy food will lead to development of awareness, behavior, abilities and knowledge needed for ensuring food security (Aktaş and Özdoğan, 2016a). 
In this context, the effect of nutritional education provided on nutritional habits of university students were enquired via this study.

\section{Purpose}

This study was carried out in order to determine the efficacy of short-term nutrition, which were undertaken for 20 hours, education in order to prevent wrong nutrition or obesity both are commonly seen in university youth.

\section{Method and Material}

\subsection{The Place and time of the study}

This research was conducted from 5 October to 11 December 2015 on students in Nursing, Midwifery, Food and Beverage Management departments of Adiyaman University.

\subsection{Population and sample selection}

The research was conducted on 395 students, including 250 female and 145 male who received nutritional education. Nutrition education provided by using modern education tools with active participation of students. Efforts have been made to introduce the concept of appropriate nutrition and the health problems that arise from improper diet in the society during education.

\subsection{Type of study}

Experimental method was used in the study. The experimental design of the study is a single group posttest (Karasar, 2006). In this model, the students who took nutrition education for the first time were given a post-test to determine their eating habits after receiving education. As the students took nutrition education for the first time pre-test application was not implemented (Tosun and Şenocak, 2012)

\subsection{Data collection}

\subsubsection{Data collection method}

The data survey was undertaken following the accomplishment of the nutritional education, a questionnaire with 20 questions was asked to the students for evaluating the education effect on students' behavior changes.

\subsubsection{Data collection tools}

After nutrition education, a questionnaire form comprising 20 questions was generated and implemented by investigating the previous studies to determine whether there was any change in their nutritional behavior (Turconi et al., 2003, Şanlier et al., 2009; Dawkins et al., 2016).

In the questionnaire form, questions were asked for determine the demographic characteristics of students, students' thoughts on healthy nutrition, and changes in consumption of students' habits after Nutrition education. The Nutrition education was given for 20 hours for 10 weeks, 2 hours in a week in 2015. Validity of the questionnaire was determined as follows; at first the questionnaire was applied to 50 people and after the necessary corrections were made, then it was applied to the students.

\subsubsection{Analyzing of Data}

The data were evaluated in the SPSS software. Mean, Standard Deviation, Percentages, chisquare test and t-test were employed for evaluation of the obtained results where necessary. The $p$ $<0.05$ significance test was applied. Gender was used as an independent variable. Reliability was acceptable with Cronbach alpha 0.77 in reliability analysis of the research. According to İslamoğlu and Alnıaç1k (2014), if Cronbach alpha value is in the acceptable range of $0.61<\alpha<0.80$, it is accepted. A 3-point Likert type scale was used to determine whether the students had changed in their eating habits after nutrition education. In the Likert test, 3 points was given for the ones who said "yes", 2 points was for "more often" and 1 point for "no". Body Mass Index (BMI) was 
Sabbağ, Ç. (2017). The evaluation of short-term nutrition education on the nutrition habits of university students. Journal of Human Sciences, 14(4), 3634-3644. doi:10.14687/jhs.v14i4.4702

calculated with weight $(\mathrm{kg}) /$ height $^{2}(\mathrm{~m})$ equation. According to BMI values, $<18.5$ was considered as underweight, $<18.518 .5-24.9$ as normal, and $\geq 25$ as overweight (WHO, 2002).

\section{Results}

The average age of the participated students to the study was $20.1 \pm 1.6$ years for the females and 21.5 \pm 2.6 years for the males, and the most of the students were female $(63.3 \%)$. While the BMI average is high for both sexes in the normal class, the ratio of overweight students in boys is about three times that of girls. Differences between genders were statistically significant $(P<0.05)$ (Table 1).

Table 1. Demographic characteristics of students

\begin{tabular}{|c|c|c|c|}
\hline & Female & Male & $\mathrm{p}$ \\
\hline Age (x \pm sd) & $20.1 \pm 1.6$ & $21.5 \pm 2.6$ & $<0.05$ \\
\hline Weight $(\mathrm{x} \pm \mathrm{sd})$ & $56.6 \pm 13.6$ & $74.1 \pm 18.2$ & $<0.05$ \\
\hline Height ( $\mathrm{x} \pm \mathrm{sd})$ & $1.63 \pm 5.5$ & $1.76 \pm 6.9$ & $<0.05$ \\
\hline $\mathrm{BMI}(\mathrm{x} \pm \mathrm{sd})$ & $21.1 \pm 2.6$ & $23.0 \pm 3.1$ & $<0.05$ \\
\hline Underweight $(<18.5)(\%)$ & 18.8 & 3.4 & $<0.05$ \\
\hline Normal (18.5-24.9) (\%) & 74.0 & 76.4 & $<0.05$ \\
\hline Overweight $\geq 25 \quad(\%)$ & 7.2 & 20.2 & $<0.05$ \\
\hline
\end{tabular}

After the nutrition education, questions were asked to the students for assessment of their thoughts on healthy nutrition. It was determined that most of the participants did not allocate enough budget for healthy eating, although girls were spending more money than male students.

The irregularity and compliance with standards of productions of foods along with the sale of local products throughout the province are reducing the confidence to these foods and as a result healthy food perception of local productions is changing. The rate of those who stated that there is not enough sales place in Adiyaman for healthy nutrition is higher in male students. They pointed out that the difficulty of accessing healthy food led them to consume fast food.

The healthy food preparation was $46.4 \%$ for the female students and $38.6 \%$ for the male students. After receiving nutrition education, female students $(86 \%)$ more behavior change in nutrition habits than male students $(78.6 \%)$. Overall, it is observed that female students have more tendency towards healthy eating after nutrition education than male students (Table 2).

Table 2. Identification of participants' thoughts on healthy eating

\begin{tabular}{lllll}
\hline Thoughts & & $\mathrm{F}(\mathrm{S} / \%)$ & $\mathrm{M}(\mathrm{S} / \%)$ & Total $(\mathrm{S} / \%)$ \\
\hline \multirow{2}{*}{$\begin{array}{l}\text { There is an increase in health eating } \\
\text { expenditures following } \\
\text { education }\end{array}$} & Yes & $73(29.2)$ & $39(26.9)$ & $112(28.4)$ \\
\cline { 2 - 5 } & No & $141(56.4)$ & $88(60.7)$ & $229(58.0)$ \\
\cline { 2 - 5 } & No idea & $36(56.4)$ & $18(60.7)$ & $54(13.7)$ \\
\hline \multirow{2}{*}{$\begin{array}{l}\text { Environment supports healthy } \\
\text { eating }\end{array}$} & Yes & $42(16.8)$ & $29(20.0)$ & $71(18.0)$ \\
\cline { 2 - 5 } & No & $150(60.0)$ & $89(61.4)$ & $239(60.5)$ \\
\cline { 2 - 5 } $\begin{array}{l}\text { Prepare healthy food when you } \\
\text { come together with your friends }\end{array}$ & No idea & $58(23.2)$ & $27(18.6)$ & $85(21.5)$ \\
\cline { 2 - 5 } & Yos & $40(16.0)$ & $22(15.2)$ & $62(15.7)$ \\
\cline { 2 - 5 } & No & $76(30.4)$ & $34(23.4)$ & $110(27.8)$ \\
\hline $\begin{array}{l}\text { Eating habit change following } \\
\text { nutrition education }\end{array}$ & Yes & $215(53.6)$ & $89(61.4)$ & $223(56.5)$ \\
\cline { 2 - 5 } & No & $35(14.0)$ & $31(21.4)$ & $66(16.7)$ \\
\hline
\end{tabular}

\section{F: Female M: Male}


Sabbağ, Ç. (2017). The evaluation of short-term nutrition education on the nutrition habits of university students. Journal of Human Sciences, 14(4), 3634-3644. doi:10.14687/jhs.v14i4.4702

To assess the impact of the nutrition education, it is necessary to test whether it turns into behavior or not. Following nutrition education, questions were asked to students to determine if there was any change in their consumption habits. In general, students reported positive changes in consumption habits following nutrition education, indicating that they pay more attention to healthy eating habits in daily life. It has been determined that the positive change is more in female students (Table 3).

In both genders, it is observed that sometimes the students do not regularly eat three meals in a day. It is seen statistically important that female students are more keen to prefer healthy foods $(p<0.05)$ by more fruit consuming $(p<0.05)$, and paying attention to the shelf life, expiry date of foods and food label $(p<0.05)$. Coke, chips, chocolate $(p<0.05)$ were found to be less consumed by female students and the difference was statistically significant. Male students were stated that had more healthy food selectivity than female students (Yes: 51.0\%, More often: 22.8\%), they pay more attention to the hours of consumption of meals compared to after education (Yes: $45.5 \%$, More often: 31.7\%), they make more physical activity (Yes: 49.7\%, More often: 27.6\%) compared to the old days. In this context, it is seen that because of especially male's thought common to have a strong physical structure, they develop nutritional behavior in this direction. The expiration of foods and food label awareness compared to before education can be said to be a significant behavioral change in terms of healthy nutrition in both genders.

Table 3. Changes in students' eating habits in relation to genders following nutrition education $(\mathrm{S} / \%)$

\begin{tabular}{|c|c|c|c|c|c|}
\hline & & Yes & More often & No & $\mathrm{p}$ \\
\hline & Gender & $\%$ & $\%$ & $\%$ & \\
\hline \multirow{2}{*}{ Eat is fun for me to after education } & $\mathrm{F}$ & 62.8 & 26.8 & 10.4 & \multirow{2}{*}{$>0.05$} \\
\hline & $\mathrm{M}$ & 63.2 & 17.4 & 19.4 & \\
\hline \multirow{2}{*}{ My healthy food choices are increased } & $\mathrm{F}$ & 56.8 & 16.8 & 26.4 & \multirow{2}{*}{$->0.05$} \\
\hline & $\mathrm{M}$ & 51.0 & 22.8 & 26.2 & \\
\hline \multirow{2}{*}{ I regularly eat all meals of the day } & $\mathrm{F}$ & 31.2 & 36.4 & 32.4 & \multirow{2}{*}{$>0.05$} \\
\hline & $\mathrm{M}$ & 29.7 & 38.6 & 31.7 & \\
\hline \multirow{2}{*}{ I pay more attention to eating time after education } & $\mathrm{F}$ & 46.8 & 29.2 & 24.0 & \multirow{2}{*}{$>0.05$} \\
\hline & $\mathrm{M}$ & 45.5 & 31.7 & 22.8 & \\
\hline \multirow{2}{*}{ I prefer healthy foods more. } & $\mathrm{F}$ & 64.0 & 27.2 & 8.8 & \multirow{2}{*}{$-<0.05^{*}$} \\
\hline & $\mathrm{M}$ & 60.7 & 16.6 & 22.8 & \\
\hline \multirow{2}{*}{ I do regular breakfast every day } & $\mathrm{F}$ & 48.8 & 22.8 & 28.4 & \multirow{2}{*}{$>0.05$} \\
\hline & $\mathrm{M}$ & 42.1 & 23.4 & 34.5 & \\
\hline \multirow{2}{*}{ I eat less fast foods and fizzy drinks following education } & $\mathrm{F}$ & 49.2 & 26.0 & 24.8 & \multirow{2}{*}{$>0.05$} \\
\hline & $\mathrm{M}$ & 49.7 & 20.0 & 30.3 & \\
\hline \multirow{2}{*}{ I consume more fruit } & $\mathrm{F}$ & 71.2 & 17.2 & 11.6 & \multirow{2}{*}{$-<0.05^{*}$} \\
\hline & $\bar{M}$ & 52.1 & 28.9 & 19.0 & \\
\hline \multirow{2}{*}{ I consume more vegetables } & $\mathrm{F}$ & 59.2 & 24.8 & 16.0 & \multirow{2}{*}{$->0.05$} \\
\hline & $\mathrm{M}$ & 53.8 & 23.4 & 22.8 & \\
\hline \multirow{2}{*}{ I do more physical activity following education } & $\mathrm{F}$ & 40.0 & 30.4 & 29.6 & \multirow{2}{*}{$>0.05$} \\
\hline & $\mathrm{M}$ & 49.7 & 27.6 & 22.8 & \\
\hline \multirow{2}{*}{ I consume fewer coke, chips, and chocolate like foods } & $\mathrm{F}$ & 50.4 & 21.2 & 28.4 & \multirow{2}{*}{$<0.05^{*}$} \\
\hline & $\mathrm{M}$ & 37.9 & 29.7 & 32.4 & \\
\hline \multirow{2}{*}{ I pay more attention to healthy cooking } & $\mathrm{F}$ & 51.6 & 24.0 & 24.4 & \multirow{2}{*}{$>0.05$} \\
\hline & $\mathrm{M}$ & 46.2 & 28.3 & 25.5 & \\
\hline \multirow{2}{*}{$\begin{array}{l}\text { I pay more attention to food label and expiration date of } \\
\text { foods }\end{array}$} & $\mathrm{F}$ & 83.6 & 5.6 & 10.8 & \multirow{2}{*}{$<0.05^{*}$} \\
\hline & $\mathrm{M}$ & 74.5 & 12.4 & 13.1 & \\
\hline
\end{tabular}


Sabbağ, C.. (2017). The evaluation of short-term nutrition education on the nutrition habits of university students. Journal of Human Sciences, 14(4), 3634-3644. doi:10.14687/jhs.v14i4.4702

According to the final test scores of the questions after the nutrition education, female students had preferred more healthy food consumption, ate more fruit, increased rate of food label reading and decreased the consumption of chips, cola, and chocolate like foods. These found to be statistically important $(\mathrm{p}<0.05)$ (Table 4).

Table 4. Comparison of post-test scores of students by gender after nutrition education.

\begin{tabular}{|c|c|c|c|c|c|}
\hline & & $\mathrm{X}$ & sd & $\mathrm{t}$ & $\mathrm{p}$ \\
\hline \multirow{2}{*}{ Eat is fun for me to after education } & $\mathrm{F}$ & 1.96 & .64 & -.641 & \multirow{2}{*}{$>0.05$} \\
\hline & $\mathrm{M}$ & 2.00 & .64 & -.641 & \\
\hline \multirow{2}{*}{ My healthy food choices are increased } & $\mathrm{F}$ & 2.40 & .76 & 1.439 & \multirow{2}{*}{$>0.05$} \\
\hline & M & 2.28 & .81 & 1.413 & \\
\hline \multirow{2}{*}{ I regularly eat all meals of the day } & $\mathrm{F}$ & 1.94 & .82 & .438 & \multirow{2}{*}{$>0.05$} \\
\hline & $\mathrm{M}$ & 1.91 & .82 & .438 & \\
\hline \multirow{2}{*}{ I pay more attention to eating time after education } & $\mathrm{F}$ & 2.17 & .85 & .378 & \multirow{2}{*}{$>0.05$} \\
\hline & $\mathrm{M}$ & 2.13 & .87 & .377 & \\
\hline \multirow{2}{*}{ I prefer healthy foods more. } & F & 2.29 & .91 & 2.969 & \multirow{2}{*}{$<0.05^{*}$} \\
\hline & $\mathrm{M}$ & 2.00 & .93 & 2.953 & \\
\hline \multirow{2}{*}{ I do regular breakfast every day } & $\mathrm{F}$ & 2.26 & .80 & .883 & \multirow{2}{*}{$>0.05$} \\
\hline & $\mathrm{M}$ & 2.18 & .79 & .888 & \\
\hline \multirow{2}{*}{ I eat less fast foods and fizzy drinks following education } & $\mathrm{F}$ & 2.23 & .83 & -.756 & \multirow{2}{*}{$>0.05$} \\
\hline & $\mathrm{M}$ & 2.29 & .78 & -.770 & \\
\hline \multirow{2}{*}{ I consume more fruit } & $\mathrm{F}$ & 2.54 & .77 & 3.540 & \multirow{2}{*}{$<0.05^{*}$} \\
\hline & $\mathrm{M}$ & 2.24 & .86 & 3.430 & \\
\hline \multirow{2}{*}{ I consume more vegetables } & $\mathrm{F}$ & 2.34 & .85 & .461 & \multirow{2}{*}{$>0.05$} \\
\hline & $\mathrm{M}$ & 2.30 & .82 & .464 & \\
\hline \multirow{2}{*}{ I do more physical activity following education } & $\mathrm{F}$ & 2.09 & .83 & -1.461 & \multirow{2}{*}{$>0.05$} \\
\hline & $\mathrm{M}$ & 2.22 & .85 & -1.454 & \\
\hline \multirow{2}{*}{ I consume fewer coke, chips, and chocolate like foods } & $\mathrm{F}$ & 2.29 & .79 & 2.490 & \multirow{2}{*}{$<0.05^{*}$} \\
\hline & $\mathrm{M}$ & 2.08 & .82 & 2.470 & \\
\hline \multirow{2}{*}{ I pay more attention to healthy cooking } & F & 2.28 & .82 & 1.205 & \multirow{2}{*}{$>0.05$} \\
\hline & $\mathrm{M}$ & 2.17 & .84 & 1.196 & \\
\hline \multirow{2}{*}{$\begin{array}{l}\text { I pay more attention to food label and expiration date of } \\
\text { foods }\end{array}$} & $\mathrm{F}$ & 2.78 & .53 & 2.548 & \multirow{2}{*}{$<0.05^{*}$} \\
\hline & $\mathrm{M}$ & 2.62 & .69 & 2.375 & \\
\hline
\end{tabular}

F: Female $\quad$ M: Male $\quad * \mathrm{P}<0.05$ statistically significant

\section{Discussion and Conclusion}

University students have inadequate and unbalanced unhealthy eating habits because of the social circle of friends, the lack of healthy food business around the campus, dwelling, and poor socioeconomic status. Especially, environmental change is associated with gaining weight; for this reason the increase in obesity or the weight loss due to malnutrition that can be observed among students, it was suggested to increasing the likelihood of other problems (Levitski et al., 2004).

The observed increase in obesity among students suggests that the likelihood of occurrence in other problems is high. The nutrition education should be taken into account during education planning in high and postgraduate to prevent such nutrition-related disorders. Education should support not only the acquisition of knowledge but also the development and change. In this context, nutrition education comprises various types of attempts targeting to positively affect the 
Sabbağ, Ç. (2017). The evaluation of short-term nutrition education on the nutrition habits of university students. Journal of Human Sciences, 14(4), 3634-3644. doi:10.14687/jhs.v14i4.4702

knowledge and behaviors of the society for preventing malnutrition. Behavioral change is the direct focus of nutrition education and it is aimed to gain positive behaviors such as eating fruit and vegetables, feed on a low fat diet, nursing baby, doing physical activity after nutrition education (Contento, 2011). In many studies, a positive relationship between increased fruit and vegetable consumption, healthy food choice by students following receiving nutrition information (Wardle et al., 2000; Aktas and Haklı 2008, Robinson-O'Brien et al., 2009). In a study undertaken by Aktas and Hakl1 (2008), healthy food preference was significantly higher in Exprimental Group (EG)

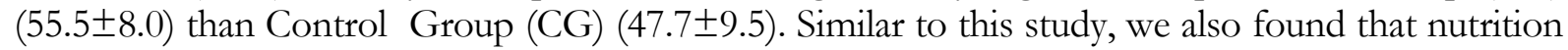
education was more effective on healthy food choices of participants. They paid much more attention to the product label information (Satia et al., 2005), skipping meals is determined to be less than the state $(\mathrm{Bu}, 2013)$.

In a meta-analysis conducted, it was revealed that knowledge increased by $33 \%$, attitude by $14 \%$ and behavior by 19\% with giving nutrition education (Contento, 2011). It is also true that in a short-time nutrition information should be supported by the behavioral changes via experiential learning as information is immediately executed (Rustad and Smith, 2013). In this context, it is necessary for a healthy generation to providing the trainings to be given including the families from the pre-school period. As the belief that the content of foods is important is higher in women (Morse and Driskell, 2009), consciousness-raising, especially in the short-term, should be prioritized. Generally, unhealthy food consumption is higher in male students (Bauer et al., 2009) which support findings of this study. Another issue that needs to be addressed in nutrition education is food and nutrition literacy. In a study, more than half $(57.0 \%)$ of the students were determined to know the concept of nutrition literacy (Aktas and Özdoğan, 2016b).

The majority of the students have a normal range of the body mass index and male students overweight proportion is higher than that of female students by $20.2 \%$ vs $7.2 \%$. Similarly, $31.3 \%$ of male students studying at Kayseri medical faculties are overweight and 13.5\% of female students are overweight. Obesity is a problem seen in school children. Obesity is known to be influenced by excessive nutrient intake, inadequate physical activity, genetic, environmental and psychological factors (Willer et al., 2009). Silveira et al. (2011) stated that excess weight may be reduced by schoolbased nutrition education and in some studies; education was seemed less effective on weight (Sobol-Goldberg et al., 2013).

As seen in the study, it was determined that female students had more healthy eating habits than male students. The ratio of healthy foods and fruit consumption and paying attention to shelf life, decreased coke and chips consumption along with food label awareness following education were higher in females which were obtained by posttest scores, and this difference between genders were statistically significant $(\mathrm{p}<0.05)$. Similar studies have shown that female students are more concerned with nutrition education and healthy eating habits are more common among them (Kim and Jang, 2007; Kostanjevec et al., 2012). In other studies, females fruit and vegetable consumption (Wagner et al., 2016), nutritional habits, behavioral and nutritional knowledge levels are found to be higher than male students (Cooke and Wardle, 2005, Şanlier et al., 2009; Na et al., 2010). Fruit and vegetable consumption is crucial against fighting to chronic illness in men and women, and it should be consumed on an average of 5 servings per day (WHO, 2005). Increased consumption is thought to be possible with nutrition education. It is stated that a favoring relationship occurs at customers who care to shelf life of nutrients and expiry date and between nutrient education (Miller and Cassady 2015). Adequate and balanced nutrition and physical activity in project groups are necessary formation and maintenance of healthy life. One of the unhealthy behaviors of university students is physical activity, one of the approaches to prevent chronic diseases (Dunstan et al., 2012; Bonevski et al., 2014). In general, the rate of physical activity and its sustainability is limited in students (Bonevski et al., 2014; Yahia et al., 2016). It was observed that male students were more likely to increase their food selectivity, to pay more attention to the consumption time, and to have more physical activity after the nutrition education. 
Many studies have found that males are keener to involve in physical activity than females (Thompson et al., 2003; Yahia et al., 2016). Thus, there is a relationship between physical inactivity and overweight among male students (Peltzer et al., 2014), and the frequency of physical activity increases after given nutrition education (Nabipour et al., 2004).

In Turkey, the rate of skipping meals, especially skipping breakfast is high in college-age students. In the $19-30$ age group, $21.6 \%$ of the males and $18.7 \%$ of the females are skipping breakfast (TBSA, 2010). It is stated that there is a positive relationship between breakfast consumption and course success (Adolphus et al., 2013) and it may be effective in lowering body mass index (Baldinger et al., 2012). It was stated student bypass one of the daily meals due to lack of appetite for males and weight control for female students ( $\mathrm{Na}$ et al., 2014). Although the ratio of those who do not bypassing meals after the education in both genders is lower than those who skip it. It is determined that mostly female students had regular breakfast every day. In a similar study, it was found that the rate of bypassing meals (Hong et al., 2010; Dehdari et al., 2014) and the rate of vaulting breakfast decreased following 20 hours long nutrition education (Geçkil and Yıldız, 2006).

The results showed that even the short-term training ie 2 hours/weef for 10 weeks provided varying positive results in the eating habits. Following nutrition education, significant changes in eating habits of students were determined. However, female students expressed more attitude change towards healthy food choice, more fruit consumption and took more care to food label reading compared to male students. But in order to ensure permanency of education, nutrition education should be a compulsory course from elementary to university.

\section{Recommendations;}

- Beginning the nutrition education in the first year of the university will ensure that healthy nutrition during the university education as this study revealed quite high efficiency of nutrition education in the second year of students.

- More comprehensive studies are needed to determine which education period is required to provide effective results on nutrition habits of the university students although 2 hours/week for 10-week education revealed significant positive results.

- It is necessary to giving nutrition education not only in certain sections but also in departments such as technical and social sciences for a healthy society.

- As practical and experimental education rather than theoretical in the school are to be able to provide more effective results.

- According to the result of the study, it was observed that the interest in nutrition education was higher in female students. It has been seen that girls achieved more healthy eating habits than male students. In this context, it is seen that the format of nutrition education towards male students needs to be reviewed.

- Access to healthy foods within the university premises by students can be established for supporting students' healthy eating habits.

- The curricular can be reviewed that will ensure more physical activity in universities as recently morning activity was incorporated to elementary and high school syllabus.

- Food fests particularly at agricultural region universities such as Adiyaman can be promoted to encourage the consumption of healthy foods via various fun activities such as eating maximum nuts at certain periods. 
Sabbağ, Ç. (2017). The evaluation of short-term nutrition education on the nutrition habits of university students. Journal of Human Sciences, 14(4), 3634-3644. doi:10.14687/ihs.v14i4.4702

\section{References}

Adolphus, K., Lawton, C. L., \& Dye, L. (2013). The effects of breakfast on behaviour and academic performance in children and adolescents. Frontiers in Human Neuroscience, 7.425.

Aktaş, N., Özdoğan, Y. (2016a). Gıda ve beslenme okuryazarlığı. Harran Tarım ve Gıda Bilimleri Dergisi, 20(2): 146-153.

Aktas, N., Özdoğan, Y. (2016b). A Study of the State of Knowing the Nutritional Literacy Concept in Turkey, Researchers World, 7(2), 46-52.

Aktas, N., \& Hakl, G. (2008). Does Nutrition Education Effect Healthy Food Preferences of Undergraduates? Issues on Education and Research: 1; 109-115 Atiner: The Athens Institute for Education and Research (G. T. Papanikos, Ed.) First Published in Athens, Greece.

Baldinger, N., Krebs, A., Muller, R., \& Aeberli, I. (2012) Swiss children consuming breakfast regularly have better functional skills project less overweight than breakfast skippers. The Journal of the American College of Nutrition, 31, 87-93.

Bauer, K.W., Larson, N.I., Nelson, M.C., Story, M., \& Neumark-Sztainer, D. (2009). Socio-environmental, personal and behavioural predictors of fast-food intake among adolescents. Public Health Nutrition, 12(10), 1767-1774.

Bonevski, B., Guillaumier, A., Paul, C., \& Walsh, R. (2014). The vocational education setting for health promotion: a survey of students' health risk behaviours and preferences for help. Health Promotion Journal of Australia, 24:185-91.

Bravo, A., Martin, N., \& Gonzalez, A. (2006). Evaluation of dietary habits of a population of university students in relation with their nutritional knowledge. Nutrición Hospitalaria, 21, 466-473

Bu, S.Y. (2013). Transitional changes in energy intake, skeletal muscle content and nutritional behavior in college students during course-work based nutrition education. Clinical Nutrition Research, 2(2), 125134.

Çekal, N. (2008). Orta Yaşlı ve Yaşı Bireylerin Beslenme Bilgi Düzeyleri. Yaşh Sorunlar Araștrma Dergisi, 1, 14-28.

Contento, I.R. (2011). Contento, Isobel R. Nutrition education : linking research, theory, and partice, 2nd Ed, 444p.

Cooke, L.J., \& Wardle, J. (2005). Age and gender differences in children's food preferences. British Journal of Nutrition, 93, 741-746.

Cooke, R., \& Papadaki, A. (2014). Nutrition label use mediates the positive relationship between nutrition knowledge and attitudes towards healthy eating with dietary quality among university students in the UK. Appetite, 83, 297-303.

Dawkins, N.L., Carter, V.L., Findlay, H.J. \& Howard, B. (2016). Responses to health knowledge and behavior questionnaire: implications for nutrition intervention. Journal Of Food And Nutritional Disorders, 2(1);1012.

Dehdari, T., Rahimi, T., Aryaeian, N., \& Gohari, M.R. (2014). Effect of nutrition education intervention based on Pender's Health Promotion Model in improving the frequency and nutrient intake of breakfast consumption among female Iranian students. Public Health Nutrition, 17(03), 657-666.

Dingman, D. A., Schulz, M. R., Wyrick, D. L., Bibeau, D. L., \& Gupta, S. N. (2014). Factors related to the number of fast food meals obtained by college meal plan students. Journal of American College Health, 62(8), 562-569.

Dunstan, D., Howard, H., Healy, G.N. \& Owen, N. (2012). "Too much sitting—a health hazard," Diabetes Research and Clinical Practice, 97(3), 368-376.

El Ansari, W., Stock, C., John, J., Deeny, P., Phillips, C., Snelgrove, S., et al. (2011). Health promoting behaviours and lifestyle characteristics of students at seven universities in the UK. Central European Journal of Public Health, 19:197

Epuru, S., \& Al Shammary, M. (2014). Nutrition knowledge and its impact on food choices among the students of Saudi Arabia. Journal of Dental and Medical Sciences, 13(1), 68-74.

Gaglianone, C.P., Taddei, J.A.D.A.C., Colugnati, F.A.B., Magalhães, C.G., Davanço, G.M., Macedo, L.D. \& Lopez, F. A. (2006). Nutrition education in public elementary schools of são paulo, brazil: the reducing risks of illness and death in adulthood project. Revista De Nutriçao, 19(3), 309-320.

Garipoğlu, M., Budak, N., Öner, N., Sağlam, Ö. \& Nişli, K. (2006). Üç farklı üniversitede eğitim gören kız öğrencilerin beslenme durumları ve vücut ağırlıklarının değerlendirilmesi. Sağhlk Bilimleri Dergisi (Journal Of Health Sciences), 15(3),173-180. 
Sabbağ, Ç. (2017). The evaluation of short-term nutrition education on the nutrition habits of university students. Journal of Human Sciences, 14(4), 3634-3644. doi:10.14687/jhs.v14i4.4702

Geçkil, E., \& Yıldız, S. (2006). Adölesanlara yönelik beslenme ve stresle başetme eğitiminin sağliği geliştirmeye etkisi. Cumburiyet Üniversitesi Hemşirelike Yüksek Okulu Dergisi, 10(2), 19-28.

Gil A. (2010). Tratado de nutrición: tomo i11 - nutrición humana en el estado de salud (2nd edition, 3rd volume). Madrid: Editorial Médica Panamericana, S.A.

Grosso, G., Mistretta, A., Turconi, G., Cena, H., Roggi, C., \& Galvano, F. (2013). Nutrition knowledge and other determinants of food intake and lifestyle habits in children and young adolescents living in a rural area of Sicily, South Italy. Public health nutrition, 16(10), 1827-1836.

Gubbels, J. S., Van Assema, P., \& Kremers, S.P. (2013). Physical activity, sedentary behavior, and dietary patterns among children. Current nutrition reports, 2(2), 105-112.

Haslam, C., Sherratt, E., Holdsworth, M., Beardsworth, A., Keil, T. \& Goode, J. (2000). Social factors associated with self-reported dietary change. Journal Of Nutrition Education, 32(6), 296-303.

Hayaloğlu, P., \& Bal, H.Ç. (2015). Üst Orta Gelirli Ülkelerde Sağlık Harcamaları ve Ekonomik Büyüme İlișkisi. Ișletme ve Iktisat Calısmalar Dergisi, 3(2), 35-44.

Hong, M., Choi, M.S., Han, Y.H., \& Hyun, T. (2010). Effect of nutrition education program developed by a public health center on preschool children's nutrition knowledge and dietary habits and the parent's dietary attitudes. Korean Journal of Community Nutrition, 15(5), 593-602.

İlhan, N., Batmaz, M., \& Akhan, L.U. (2010). Üniversite öğrencilerinin sağlıklı yaşam biçimi davranışları. Maltepe Üniversitesi Hemşirelik Bilim ve Sanatı Dergisi, 3(3), 34-44.

Irwin, J.D. (2004). Prevalence of university students' sufficient physical activity: a systematic review. Perceptual and Motor Skills, Jun; 98,927-43.

İslamoğlu, A. H. \& Alnıaçı, Ü. (2014). Sosyal bilimlerde araştırma yöntemleri (spss uygulamalı). İstanbul, Beta Yayıncilik.

Karasar, N. (2006). Bilimsel Araştırma Yöntemi; Kavramlar, İlkeler, Teknikler (16.baskı). Ankara: Nobel Yayinları.

Khajvy Shojaei, K., Parsa, C., Fallah, N. (2001). Knowledge, attitude, behavior of pregnant women who referred to university hospitals in Tehran. Journal of Gorgan University of Medical Sciences, 8(1),70-5

Kim, Y.H. \& Jang, M.R. (2007). A research on analysis of eating habits and textbook contents for efficient nutrition education of elementary school students in Gangneung city. Journal Of The Korean Dietetic Association, 13(4), 379-388.

Kostanjevec, S., Jerman, J. \& Koch, V. (2012). The influence of nutrition education on the food consumption and nutrition attitude of schoolchildren in Slovenia. Online Submission.

Lange, K.W. (2017). Movement and nutrition in health and disease. Movement and Nutrition in Health and Disease, 1:1-2.

Lee, Y.J., Lee, H.J., \& Lee, K.H. (2014). Effects of 16-Class Nutrition Education on Middle School StudentsDietary Behavior and Nutritional Knowledge. The Korean Journal of Food And Nutrition, 27(5), 826-836.

Levitsky, D.A., Halbmaier, C.A. \& Mrdjenovic, G. (2004). The freshman weight gain: a model for the study of the epidemic of obesity. International Journal Of Obesity And Related Metabolic Disorders, 28(11),14351442

Miller, L.M.S., \& Cassady, D.L. (2015). The effects of nutrition knowledge on food label use. A review of the literature. Appetite, 92, 207-216.

Morse, K.L., Driskell, J.A. (2009). Observed sex differences in fast-food consumption and nutrition selfassessments and beliefs of college students. Nutrition Research, 29:173-179

Na, J.A., Lee, J.H., \& Kim, M.H. (2014). Study on the satisfaction for school food service and dietary habits of middle school students in Sejong Special Self-Governing City. The Korean Journal of Food And Nutrition, 27(3), 369-382.

Na, S.Y., Ko, S.Y., Eom, S.H., \& Kim, K.W. (2010). Intakes and beliefs of vegetables and fruits, self-efficacy, nutrition knowledge, eating behavior of elementary school students in kyunggi area. Korean Journal of Community Nutrition, 15(3), 329-341.

Nabipour, I., Imami, S.R., Mohammadi, M.M., Heidari, G., Bahramian, F., Azizi, F., Khosravizadegan, Z., Pazoki, R., Soltanian, A.R., Ramazanzadeh, M., Emadi, A., Arab, J., Larijani, B. (2004). A schoolbased intervention to teach 3-4 grades children about healthy heart; the Persian Gulf healthy heart 3643roject. Indian Journal of Medical Sciences, 58(7), 289-96. 
Sabbağ, Ç. (2017). The evaluation of short-term nutrition education on the nutrition habits of university students. Journal of Human Sciences, 14(4), 3634-3644. doi:10.14687/jhs.v14i4.4702

Peltzer, K., Pengpid, S., Samuels, T., Özcan, N.K., Mantilla, C., Rahamefy, O.H., \& Gasparishvili, A. (2014). Prevalence of overweight/obesity and its associated factors among university students from 22 countries. International journal of environmental research and public health, 11(7), 7425-7441.

Robinson-O'brien, R., Story, M. \& Heim. S. (2009). Impact of garden-based youth nutrition intervention programs: a review. Journal Of The American Dietetic Association, 109, 273-280.

Rtveladze, K., Marsh, T., Barquera, S., Romero, L.M.S., Levy, D., Melendez, G., \& Brown, M. (2014). Obesity prevalence in Mexico: impact on health and economic burden. Public health nutrition, 17(01), 233-239.

Rustad, C., \& Smith, C. (2013). Nutrition knowledge and associated behavior changes in a holistic, shortterm nutrition education intervention with low-income women. Journal of Nutrition Education and Behavior, 45(6), 490-498.

Şahin, H., Aykut, M., Öztürk, A., Yllmaz, M., Gün, İ., Çelik, N., \& Durmuş, H. (2015). Obesity Prevalence and Related Factors among Medical Students in Kayseri. Erciyes Medical Journal/Erciyes Tip Dergisi, 37(2). 51-8.

Şanlıer, N., Konaklığlu, E., \& Güçer, E. (2009). Gençlerin beslenme bilgi, alışkanlık ve davranışları ile beden kütle indeksleri arasındaki ilişki. Gazi Üniversitesi Gazi Eğitim Fakültesi Dergisi, 29(2), 333-352.

Satia, J.A., Galanko, J.A., \& Neuhouser, M.L.(2005). Food nutrition label use is associated with demographic, behavioral, and psychosocial factors and dietary intake among african americans in north carolina. Journal Of The American Dietetic Association, 105, 392-402.

Silveira, J.A., Taddei, J.A., Guerra, P.H., Nobre, M.R., (2011). Effectiveness of school-based nutrition education interventions to prevent and reduce excessive weight gain in children and adolescents: a systematic review. Journal of Pediatrics (Rio J) 87, 382-392.

Sobol-Goldberg, S., Rabinowitz, J., \& Gross, R. (2013). School-based obesity prevention programs: A metaanalysis of randomized controlled trials. Obesity, 21(12), 2422-2428.

Spronk, I., Kullen, C., Burdon, C. \& O'connor, H. (2014). Relationship between nutrition knowledge and dietary intake. British Journal of Nutrition, 111(10), 1713-1726.

Thompson, A.M., Baxter-Jones, A.D., Mirwald, R.L., \& Bailey, D.A. (2003). Comparison of physical activity in male and female children: does maturation matter?. Medicine and Science in Sports and Exercise, 35(10), 1684-1690.

TBSA. (2010). Türkiye beslenme ve sağlık araştırması 2010. Türkiye'de Beslenme ve Sağlık Durumu, Sağllk Bakanlı̆̆1 Sağlık Araştırmaları Genel Müdürlüğ̈̈ Yayın No : 931, 607s.

TSI. (2015). Health Expenditure Statistics, 2014. Turkish Statistical Institute. http://www.turkstat.gov.tr/PreHaberBultenleri.do?id=18853

Tosun, C., \& Şenocak, E. (2012). Üniversite öğrencilerinin probleme dayalı öğrenme (pdö) ortamı hakkındaki görüşleri. The Journal of Academic Social Science Studies, 5(8), 1167-1184.

Turconi, G., Celsa, M., Rezzani, C., Biino, G., Sartirana, M.A., \& Roggi, C. (2003). Reliability of a dietary questionnaire on food habits, eating behaviour and nutritional knowledge of adolescents. European Journal of Clinical Nutrition, 57(6); 753-763.

USDA. (2012). Nutrition - Website: National Institute of Food and Agriculture. Available At: Www.Nifa.Usda.Gov/Nutrition.Cfm.

Wardle, J., Parmenter. K., \& Waller, J. (2000). Nutrition knowledge and food intake. Appetite 34, 269-275.

WHO. (2002). Resolution Wha53.23. Diet, Physical Activity and Health. In: Fifty-Fifth World Health Assembly. Geneva; 2002. V.1.

WHO. (2005). Report of a joint FAO/WHO Workshop, 1-3 September 2004. Kobe, Japan, Geneva: 2005. World Health Organization. Fruit and vegetable for health.

WHO. (2010). Guidelines for Preventive and Social Medicine/Community World Health Organization, Regional Office for South-East Asia, India. $22 \mathrm{P}$.

Willer, C., Speliotes, E., Loos, R., Shengxu, L., Lingren, C., \& Heid, I. (2009). Six new loci associated with body mass index highlight a neuronal influence on body weight regulation. Nature Genetics, 41 (1), 2534.

Yahia, N., Wang, D., Rapley, M., \& Dey, R. (2016). Assessment of weight status, dietary habits and beliefs, physical activity, and nutritional knowledge among university students. Perspectives in public health, 136(4), 231-244. 